\title{
The Effect on Certain Plants of altering the Daily Period of Light.
}

\author{
BY \\ J. ADAMS, \\ Central Experimental Farm, Ottawa, Canada.
}

DLANTS growing within the Arctic Circle complete their development during the summer months at a time when there is continuous illumination during the whole twenty-four hours. From this it may be inferred that a daily alternation of light and darkness is not essential for the growth of certain plants.

On the other hand, plants growing at places between the Equator and the Arctic Circle are subject to an alternation of light and darkness during each day, the relative length of which varies according to the latitude and the time of year. At a spot half-way between the Equator and the polethat is, in latitude $45^{\circ}$-during the summer months the period of daylight is much in excess of the daily period of darkness. In such localities, assuming that the rainfall and soil are suitable, there is an abundant development of natural vegetation. The question then arises-Is this alternation of light and darkness necessary for the growth of such vegetation, and what would be the result if the relative length of day and night were artificially altered, other factors being left as far as possible the same? Supposing the periods of light and darkness were made approximately equal during each 24 hours, what would be the effect on plants as regards (I) the height of the stem, (2) the total weight of the plant, (3) the time of coming into flower? It was to obtain some further information on these subjects that the experiments detailed below were undertaken.

Before describing these experiments in some detail it will be advisable to review briefly some of the conclusions arrived at by previous investigators.

Kjellman (3) experimented with Lepidium sativum in the Arctic regions, allowing some plants to remain exposed to continuous illumination for 24 hours, while other plants were kept dark from 8 p.m. to 8 a.m. After two months he found that the illuminated plants were both taller and heavier than those which had been kept in the dark for I 2 hours daily. Similar differences, but even more pronounced, were found by him in his experiments with Arctic plants such as Cochlearia fenestrata and Catabrosa algida.

Curtel's experiments (5) in Norway during a period of continuous

[Annals of Botany, Vo1. XXXVII. No. CXLV. January, I923.] 
sunlight proved that assimilation proceeded uninterruptedly, the minimum occurring at midnight, at the time of least illumination.

He also concluded (10), from observations made upon the influence of diffuse light on flowers, that the flowers were less brilliant in colour and fewer in number, and the fruits were smaller in diffuse light than in direct illumination, while very diffuse light made the formation of flowers impossible.

Bailey (6), using a protected electric arc light during half the night, was able to hasten the development of lettuce in a greenhouse by two weeks.

Vöchting (7) proved that under a weak illumination the formation of flowers in numerous phanerogams was either entirely prevented or only incompletely achieved. He found that the formation of flowers was closely connected with the activity of the leaves.

Bonnier (9) found, as the result of exposing plants to continuous electric light, that there was a much greater development of chlorophyll as well as other internal differences.

Pfeffer (12) states that "within certain limits, a decrease in the illumination produces an accelerated rate of growth in a phototonic plant and an increase a diminished rate'.

On the other hand, Macdougal (13) appears to take a different view. He says: "The same results have been attained in another form by the exposure of growing plants to continuous exposure to electrical illumination, or to an illumination in which daylight was supplemented by nocturnal illumination from electric arcs, or flames. In all such instances the amount of growth, as indicated by the length of the shoots and of the separate members, was greater than under ordinary conditions of alternating daylight and darkness. If light exerted a direct retarding, or paratonic, influence upon the processes of growth, such results would be impossible.'

Schimper (14), speaking of the action of continuous light during summer, states that it has a retarding action on growth, but furthers assimilation and the formation of pigments and other substances. $\mathrm{He}$ further states that growth in length of stems and roots is at its optimum when light is totally excluded.

Regarding the action of light on the development of flowers, Schimper continues: "The minimum of light for the formation of flowers is lower for shade plants than for sun plants ; yet the former generally produce fewer flowers than do the latter. The interior of a forest is poorer in flowers than a meadow, and certain regions with intense or prolonged illumination, such as the higher regions of vegetation in mountains, polar countries, and many deserts, are characterized by a great abundance of flowers. In such cases, however, other factors co-operate.'

Osterhout (15), commenting on the stunted stems of plants growing at high altitudes, states that 'the plants in question are comparatively warm 
during the day when the sun is shining, but cool off very rapidly after sunset and remain cold during the night. Normally the greatest growth takes place at night, hence chilling them at this time explains, in part at least, their stunted growth.'

Warming (18) says: 'The development of plants depends not only upon the intensity but also upon the duration of the light to which they are exposed. For instance, in Finland or the north of Norway barley ripens its grain in eighty-nine days from the day of sowing, but in Schonen (in Sweden, $55^{-} 7^{\circ}$ N.) it requires Ioo days, despite the higher temperature and the more intense light ; and the explanation of this must in part be that in the former places prolonged illumination promotes anabolism.'

He further states that 'intense light retards the growth of the shoot; consequently heliophytes are compact and have short internodes, but sciophytes have elongated internodes; species clothing the forest soil are mainly tall and long-stemmed'.

By the use (19) of an acetylene light Craig was able to force the development of flowers within a shorter time in the case of Easter lilies.

Hayden and Steinmetz's experiments (20) on the ripening of String Beans under electric lamps proved that they ripened in about half the time required for those grown under natural conditions with daylight only.

Palladin (22) says that 'plants grow more. slowly by day than by night, so that it appears that light exerts a retarding influence upon growth'.

De Besteiro and Durand $(23,24)$, experimenting with Garden Pea under light of intensities of $\frac{1}{9}, \frac{1}{3}, \frac{1}{2}$, and full sunlight, found that the dry weight of the entire plants increased with the intensity of light and in the proportions of $2,6,7$, and II.

Wiessmann (25) found as the result of growing Oat plants on a roof and in a court that those on the roof, which were more fully exposed to the light, not only stooled better, but also flowered and ripened seed earlier and had a greater yield of both straw and grain than the plants grown in the court.

Garner and Allard $(27,32)$ experimented with a large number of plants, some of which were kept in the dark for a certain number of hours daily. Different species behaved in different ways under this treatment, but they found that some species so darkened came into flower much earlier than other members of the same species which were exposed to the full period of daylight. Another conclusion reached was that 'in all species thus far studied the rate of growth is directly proportional to the length of the daily exposure to light'.

Adams (28), experimenting with Flax, found that the plants exposed to the full period of daylight were taller and heavier and reached the flowering stage sooner than those darkened for a number of hours each day.

By employing continuous illumination (31) by n:eans of an Osram 
lamp Klebs was able to make a small beech-tree develop leafy shoots continuously for eight months and an oak-tree for seven months, three of which were in winter. He also states that humidity promotes growth and at the same time hinders the formation of flowers. He further adds that the essential condition for flower-production is the accumulation of carbohydrates in the plant, a result which is directly dependent on the amount of photosynthesis. Hence, by using artificial illumination from an Osram lamp, he was able to make Sempervivum flower at any time of the year.

It is evident from the above summary that considerable difference of opinion exists among observers as to (I) the effect of light on growth, that is, extension in length, and (2) the effect of light on the production of flowers. In order to throw some further light on this problem two series of tests with different plants were carried out during the summers of I920 and I92I. The experiments made in I920 were carried out in the greenhouse, while those of I92I were conducted on plants growing in open ground for the most part.

\section{Greenhouse Experiments, I920.}

Four species of plants were used for the experiments, namely, Flax, Wheat, Sunflower, and White Mustard. The seeds were sown in six-inch pots. Six pots were planted with each species of seed, three being exposed to the light, while the other three were kept dark for a short time each day while the experiments lasted. The experimental pots were darkened by being covered with large flower-pots inverted, in which the hole in the bottom had been tightly closed with a cork. At first pots of $9 \frac{1}{2}$ inches in diameter were employed, and towards the end of the experiments, when the Sunflowers were too tall to be covered by pots, they were placed in a wooden cupboard from which light was excluded.

In experiments with environmental factors it is extremely difficult so to arrange the conditions that only one factor will vary at the same time. The pots were not watered during the time of darkening, so that both the pots exposed and those covered received the same amount of water each day. It is conceivable, however, that slightly more water would pass into the air from the soil of the pots left exposed than in the case of the pots covered. It is also possible that the temperature inside the cover might differ slightly from that of the rest of the greenhouse. It is not probable, however, that the difference in either case would be so appreciable as to have much effect on the final result. Some observations on the temperature inside the cover were made in the case of the experiments carried out in $192 \mathrm{I}$.

To indicate the exact procedure followed, a more extended account of the operations in the case of Flax is given, while for other species only a summary of results is given in each case. 


\section{Flax, 1920 .}

The three pots exposed to light were labelled $\mathrm{L}_{\mathrm{I}}, \mathrm{L}_{2}$, and $\mathrm{L}_{3}$, while the three darkened periodically were marked $\mathrm{D}_{1}, \mathrm{D}_{2}$, and $\mathrm{D}_{3}$. The seeds were sown on $3^{\mathrm{I}} \mathrm{May}$, and after they had germinated and grown considerably several of the seedlings were pulled up in order to give the remainder more room to grow. The final thinning out took place on $8 \mathrm{June}$, ten seedlings of nearly equal vigour being left in each pot. The heights of these seedlings were carefully measured before any of the plants were darkened; the heights were again taken at the end of the experiment, as well as the total weight of the plants after they had been pulled up by the roots and the earth shaken off.

The dates, duration of darkening, and weather conditions were as follows :

\begin{tabular}{|c|c|c|c|c|}
\hline 9 June & Darkened & 10.30 & to $\mathrm{II} \cdot 30$ & Sunny \\
\hline I0 , , & ,, & $9 \cdot 30$ &, 10.30 & Cloudy, then sunny \\
\hline IO & , & 3.20 &, 4.20 & Sunny \\
\hline I I &, & 10.20 & , II.2O & Cloudy \\
\hline I 2 & , & 10.35 &, I I.35 & Cloudy \\
\hline I 4 & , & 10.30 &, I I.30 & Mostly sunny \\
\hline I 5 & , & 10.30 &, II.30 & Mostly cloudy \\
\hline 16 & , & I0.25 &,$\quad$ II.25 & Sunny \\
\hline 17 & , & IO. IO &, I I. 40 & Mostly sunny \\
\hline I 8 & , & IO. I 5 &, I I.I5 & Cloudy \\
\hline I9 & , & 10.05 &,,$\quad 11 \cdot 35$ & Sunny \\
\hline $2 I$ & , & IO. I 5 & , II.I 5 & Cloudy \\
\hline 23 &,, & 10.00 & , I 2.00 & Sunny and cloudy \\
\hline 24 & , & 10.30 &,$\quad$ II.3O & Sunny \\
\hline 25 & , & 10.00 &, II.OO & Mostly sunny \\
\hline 25 & , & 2.30 & $\Rightarrow \quad 3.30$ & Sunny and cloudy \\
\hline 26 & , & 11.40 & 12.40 & Sunny and cloudy \\
\hline , & , & $9 \cdot 3.5$ &, Io.40 & Cloudy \\
\hline , & , & IO.I 5 & , II.IO & Cloudy \\
\hline 30 & , & $9 \cdot 35$ &,,$\quad 1 \mathrm{I} .35$ & Cloudy \\
\hline July & , & 10.25 &,, II. 25 & Cloudy \\
\hline , & , & 10.00 & , I 2.00 & Sunny \\
\hline , & , & 10.00 & , II.OO & Sunny \\
\hline , & , & 10.05 & , II.O5 & Sunny \\
\hline
\end{tabular}

It will be seen, therefore, that the period of darkening extended from 9 June to 6 July. The plants were darkened on twenty-two days. The total period of darkening amounted to twenty-eight hours, namely, nineteen times for one hour, two times for one and a half hours, and three times for two hours. All the occasions of darkening were a.m., except three which were partly or wholly p.m. About half of the times of darkening were sunny and the other half cloudy.

The results obtained from each set of plants were as follows:

The first column gives the average height of each plant on 9 June; the second column the average height on 7 July; the third column the height of the tallest plant on 7 July; and the fourth column the total weight (including roots) on 7 July. 


\begin{tabular}{|c|c|c|c|c|}
\hline & $\begin{array}{c}\text { Average height } \\
\text { on } 9 \text { June. } \\
\text { mm. }\end{array}$ & $\begin{array}{l}\text { Average height } \\
\text { on } 7 \text { July. } \\
\text { mm. }\end{array}$ & $\begin{array}{l}\text { Tallest on. } \\
7 \text { July. } \\
\text { mm. }\end{array}$ & $\begin{array}{c}\text { Total } \\
\text { weight. } \\
\text { grm. }\end{array}$ \\
\hline $\begin{array}{l}\mathrm{L}_{1} \\
\mathrm{~L}_{2} \\
\mathrm{~L}_{3}\end{array}$ & $\begin{array}{l}26 \cdot 9 \\
26 \cdot 4 \\
27 \cdot 6\end{array}$ & $\begin{array}{l}34 \mathrm{I} \cdot 3 \\
4 \mathrm{I} 7 \cdot 7 \\
45^{\mathrm{I} \cdot 2}\end{array}$ & $\begin{array}{l}380 \\
482 \\
500\end{array}$ & $\begin{array}{l}\text { I } 3 \cdot 720 \\
\text { I } 6 \cdot 470 \\
\text { I } 5 \cdot 400\end{array}$ \\
\hline Average & 27.0 & 403.4 & 454 & ${ }^{1} 5 \cdot 197$ \\
\hline $\begin{array}{l}\mathrm{D}_{1} \\
\mathrm{D}_{2} \\
\mathrm{D}_{3}\end{array}$ & $\begin{array}{l}24 \cdot 8 \\
27 \cdot 1 \\
25 \cdot 8\end{array}$ & $\begin{array}{r}307 \cdot 9 \\
313 \cdot 9 \\
321 \cdot 2\end{array}$ & $\begin{array}{l}355 \\
365 \\
355\end{array}$ & $\begin{array}{l}\text { I } 5 \cdot 670 \\
\text { I } 3 \cdot 700 \\
\text { I } 3 \cdot 710\end{array}$ \\
\hline Average & 25.9 & $3^{I} 4 \cdot 3$ & $35^{8}$ & 14.360 \\
\hline
\end{tabular}

While the unshaded plants were at the beginning of the experiment on 9 June 4.2 per cent. taller than the darkened set, at the end of the experiment on 7 July the unshaded lot were 28.3 per cent. taller than the other set.

\section{Wheat, 1920 .}

The period of darkening was similar to that of Flax from 9 June to 5 July and covered altogether twenty-seven hours.

The seeds were sown on $3 \mathrm{I}$ May. On 8 June the number of seedlings was reduced to ten in each pot. The heights of the seedlings were measured on 9 June, while on 6 July the total weight of the stem and leaves was determined for each set. The figures were:

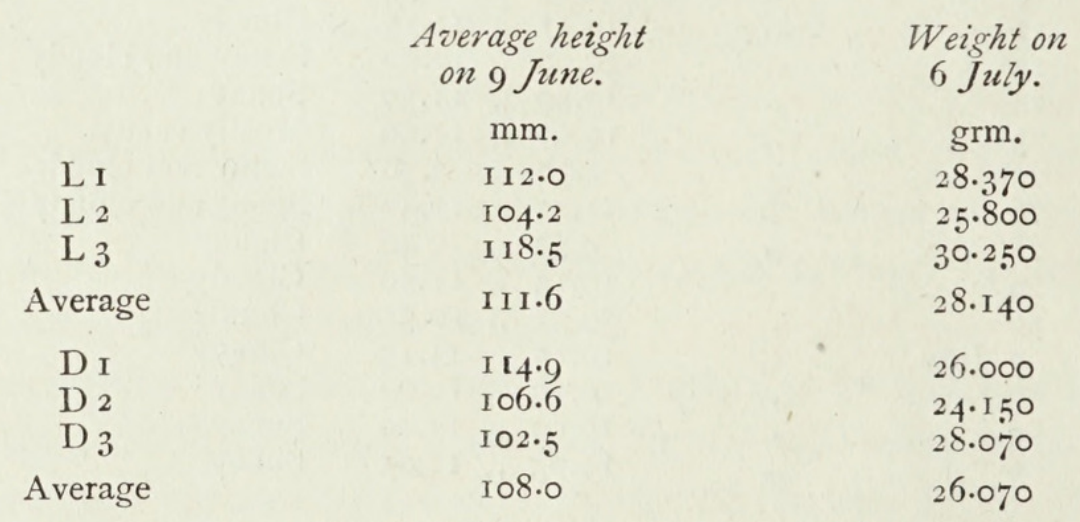

The average height of the unshaded plants on 9 June was 3.3 per cent. above that of the darkened set. The weights were presumably in the same proportion. On 6 July the average weight of the unshaded plants was $7 \cdot 9$ per cent. above that of the others.

\section{Sunflower, 1920 .}

The periods of darkening were similar to those of Flax from 9 June to 6 July. On 7 July the plants were darkened for one hour, making the total time of covering altogether twenty-nine hours.

The seeds were sown on $3 \mathrm{I}$ May. On 7 June the seedlings were reduced to ten in each pot. On 9 June the heights of the seedlings were 
measured, and on 8 July the heights were again measured, after which the plants were pulled up and weighed after the earth adhering to the roots had been removed as far as possible. The figures were:

\begin{tabular}{|c|c|c|c|c|}
\hline & $\begin{array}{c}\text { Average height } \\
\text { on } 9 \text { June. } \\
\text { mm. }\end{array}$ & $\begin{array}{c}\text { Average height } \\
\text { on \& July. } \\
\text { mm. }\end{array}$ & $\begin{array}{c}\text { Tallest on } \\
\text { 8 July. } \\
\text { mm. }\end{array}$ & $\begin{array}{l}\text { Total } \\
\text { werght. } \\
\text { grm. }\end{array}$ \\
\hline $\begin{array}{l}\mathrm{L}_{1} \\
\mathrm{~L}_{2} \\
\mathrm{~L}_{3}\end{array}$ & $\begin{array}{l}35 \cdot 3 \\
29 \cdot 8 \\
30 \cdot 3\end{array}$ & $\begin{array}{l}554 \cdot 5 \\
563.5 \\
537 \cdot 5\end{array}$ & $\begin{array}{l}607 \\
635 \\
580\end{array}$ & $\begin{array}{l}\mathrm{I} 24.820 \\
\mathrm{I} 35.380 \\
\mathrm{I} 2 \mathrm{I} \cdot \mathrm{I} 3 \mathrm{O}\end{array}$ \\
\hline Average & $3^{2 \cdot 1}$ & $55^{\mathrm{I}} \cdot 8$ & 607 & 127.110 \\
\hline $\begin{array}{l}\mathrm{D}_{1} \\
\mathrm{D}_{2} \\
\mathrm{D}_{3}\end{array}$ & $\begin{array}{l}37 \cdot 1 \\
36 \cdot 5 \\
25 \cdot 9\end{array}$ & $\begin{array}{l}548 \cdot 7 \\
585 \cdot 7 \\
484 \cdot 4\end{array}$ & $\begin{array}{l}650 \\
625 \\
54^{\circ}\end{array}$ & $\begin{array}{l}\text { II } 9.020 \\
\text { I } 32 \cdot 120 \\
\text { I09.650 }\end{array}$ \\
\hline Average & $33 \cdot 2$ & 539.6 & $60_{5}$ & 120.260 \\
\hline
\end{tabular}

While the average height of the unshaded plants on 9 June was 3.3 per cent. less than that of those subsequently darkened, the height of the unshaded plants on 8 July was $2 \cdot 2$ per cent. more than that of the other set.

\section{White Mustard, I920.}

The seeds of this species were sown on the same date as those previously mentioned, and the period of darkening was similar, but towards the end of the experiments all the plants became so badly affected with green fly that no satisfactory results could be deduced from them. Accordingly another set of experiments was started.

The plants were darkened on sixteen days between the I2th and 29th of July. They were covered altogether eighteen hours, the sky during one half of the time being sunny and during the other half cloudy. The heights and final weights of the plants were determined as in the foregoing experiments. In addition, the number of flower-buds present in each pot was observed before the plants were pulled up in order to be weighed.

The seeds were sown on 8 July. On I 2 July the seedlings were thinned, ten being left in each pot, the heights of which were determined. The heights were again measured on 23 July. The complete figures were as follows :

\begin{tabular}{|c|c|c|c|c|c|c|}
\hline & $\begin{array}{l}\text { Average } \\
\text { height on } \\
\text { I } 2 \text { July. }\end{array}$ & $\begin{array}{c}\text { Average } \\
\text { height on } \\
23 \text { July. }\end{array}$ & $\begin{array}{l}\text { Average } \\
\text { height on } \\
30 \text { July. }\end{array}$ & $\begin{array}{l}\text { Tallest on } \\
3^{\circ} \mathrm{Jully} \text {. }\end{array}$ & $\begin{array}{l}\text { No. of } \\
\text { flower } \\
\text { buds. }\end{array}$ & $\begin{array}{l}\text { Total } \\
\text { weight. }\end{array}$ \\
\hline $\mathrm{L}_{\mathrm{I}}$ & $\begin{array}{l}\mathrm{mm} . \\
13.0\end{array}$ & $\begin{array}{l}\mathrm{mm} . \\
73.9\end{array}$ & & $\begin{array}{l}\mathrm{mm} . \\
\mathrm{I} 73\end{array}$ & 7 & $\begin{array}{l}\text { grm. } \\
20.000\end{array}$ \\
\hline $\mathrm{L}_{2}$ & $\mathrm{I} 3 \cdot 2$ & $7^{2 \cdot 5}$ & 146.0 & $\begin{array}{l}194 \\
\end{array}$ & Io & I 7.950 \\
\hline $\mathrm{L}_{3}$ & I $2 \cdot I$ & 78.9 & 176.6 & 2 I 5 & 9 & $22 \cdot 75^{\circ}$ \\
\hline Average & I 2.8 & $75 \cdot \mathrm{I}$ & ${ }^{1} 5^{6} \cdot 3$ & I94 & $8 \cdot 7$ & 20.230 \\
\hline $\begin{array}{l}\mathrm{D}_{1} \\
\mathrm{D}_{2} \\
\mathrm{D}_{3}\end{array}$ & $\begin{array}{l}\text { I } 2.1 \\
\text { I0. } 6 \\
\text { I } 2.0\end{array}$ & $\begin{array}{l}55 \cdot 0 \\
58 \cdot 3 \\
67 \cdot 5\end{array}$ & $\begin{array}{l}\text { I I } 4.6 \\
\text { I } 26.2 \\
\text { I } 34.6\end{array}$ & $\begin{array}{l}\text { I } 45 \\
\text { I } 58 \\
169\end{array}$ & $\begin{array}{l}5 \\
4 \\
7\end{array}$ & $\begin{array}{l}\mathrm{I} 3.570 \\
\mathrm{I} 6.000 \\
\mathrm{I} 4.050\end{array}$ \\
\hline Average & I 1.6 & $60 \cdot 3$ & $\begin{array}{c}125 \cdot I \\
G\end{array}$ & I57 & $5 \cdot 3$ & $\mathrm{I} 4.54^{\circ}$ \\
\hline
\end{tabular}


The average height on I 2 July of the unshaded plants over those shaded was 10.3 per cent. ; on 23 July this had increased to 24.5 per cent., while on 30 July it was 24.9 per cent.

\section{Experiments in Frame, I92I.}

The first set of experiments during I 92 I was made with seeds planted in the soil within the frame. The under surface of the windows used as a roof was covered with sheets of brown paper firmly secured to exclude the light. The check lot of plants in a frame immediately adjoining the first was left uncovered throughout the experimental test.

It was found in practice that this method was less satisfactory than the tests carried out in the greenhouse or the open greund, as the factors other than light were more difficult to control. More moisture was evaporated on sunny days from the soil of the uncovered frame than from the one that was darkened. This was remedied to some extent by watering the uncovered plot occasionally. The temperature inside the covered frame as well as the relative humidity were higher than in the adjacent frame left uncovered. On 10 June the temperature at $3.25 \mathrm{p} . \mathrm{m}$. was $101^{\circ} \mathrm{F}$. inside the frame, while it was $95^{\circ} \mathrm{F}$. outside it. The relative humidity at the same time was 57 inside the frame and $5 \mathrm{I}$ outside. Notwithstanding these difficulties it seems advisable to give the results obtained, as they serve to corroborate the figures obtained by other methods.

The darkening of the frame extended from the 2 nd to the 25 th of June and took place on nineteen days in all. The total duration of darkening amounted to eighty-five and a half hours, or an average of three hours thirty-four minutes for each of the twenty-four days during which the experiment lasted. The shortest period of darkening the frame on any one day was two hours, and the longest six hours, while the commonest was five hours. The average length of day between the 2nd and 25 th of June, measured from sunrise to sunset, amounted to fifteen hours thirty-four minutes. The effect of covering the frame was to make the daily amounts of daylight and darkness equal during the twenty-four days of the experiment. The weather during fifteen of these days was bright and sunny. Care was taken to ensure that the frame was not covered when rain was falling.

The plants experimented with were Flax, Wheat, and Soy Bean.

\section{Flax in Frame, I92I.}

The seeds were sown in two rows on 23 May, one row in each frame. On 2 June seventy-eight plants were left in each row, and on 2I June the number was still further reduced, thirty-two being left in the uncovered frame and thirty-one in the one darkened. 
In the frame which was constantly exposed to light the first flower opened on 5 July, on II July there were fifteen plants in flower, and on I2 July there were sixteen plants in flower.

In the darkened frame the first flower did not open until i I July, while on I 2 July two plants were in flower.

\section{Wheat in Frame, I92I.}

One row of seeds was sown in each frame on 23 May, and on 2 June twenty-six plants were left in each row.

In the uncovered row five plants were in ear on 7 July, and on I I July there were twenty-two in ear. The first ears, three in number, in the covered row did not make their appearance until I I July.

The plants were pulled up on $\mathrm{I} 3 \mathrm{July}$ and gave the following results :

$\begin{array}{lccccc} & \begin{array}{c}\text { Average } \\ \text { height. }\end{array} & \begin{array}{l}\text { Tallest } \\ \text { plant; }\end{array} & \begin{array}{c}\text { Total } \\ \text { weight. }\end{array} & \begin{array}{c}\text { No. of } \\ \text { plants } \\ \text { in ear. }\end{array} & \begin{array}{c}\text { Total No. } \\ \text { of ears. }\end{array} \\ & \mathrm{mm} . & \mathrm{mm} . & \text { grm. } & & \\ \text { Plants exposed to light } & 497.5 & 780 & \mathrm{I} 27.57 & 25 & 49 \\ \text { Plants covered } & 316.8 & 479 & 99 \cdot 22 & \text { I I } & \text { II }\end{array}$

\section{Soy Bean in Frame, I92I.}

One row of seeds was sown in each frame on 23 May, and twenty-five plants were left in each row on 2 June. This number was reduced to twenty-three on 13 June.

In the uncovered row two came into flower on $5 \mathrm{July}$, and on 7 July three were in flower. In the covered row the first plant came into flower on 7 July.

The plants were pulled up on I 3 July and were measured and weighed with the following results:

$\begin{array}{lcccc} & \begin{array}{c}\text { Average } \\ \text { height. }\end{array} & \begin{array}{c}\text { Tallest } \\ \text { plant. }\end{array} & \begin{array}{c}\text { Total } \\ \text { weight. }\end{array} & \begin{array}{c}\text { No. of plants } \\ \text { in flower. }\end{array} \\ & \mathrm{mm} . & \mathrm{mm} . & \mathrm{grm} . & \\ \text { Plants exposed to light } & \mathbf{2 5 8 \cdot 2} & 394 & 255 \cdot \mathrm{I} 5 & 23 \\ \text { Plants covered } & 340 \cdot 3 & 475 & 283.50 & 22\end{array}$

The plants in the covered row were growing in slightly better soil. The figures should be compared with those obtained from the plants grown in the open ground, which are given farther on.

\section{Experiments in Open Ground, I92I.}

In order to keep all the factors except the amount of light as nearly as possible the same, it was found desirable to use wooden boxes for the purpose of excluding light from each set of experimental plants. The use of wooden coverings tended to lessen the difference in temperature and relative 
humidity between the air surrounding the shaded plants and that around the plants left uncovered. For example, on 18 June at 10.55 a.m. the temperature of the air inside one of the wooden boxes was $76^{\circ} \mathrm{F}$., while outside the box it was $72^{\circ} \mathrm{F}$. On 20 June at $3.25 \mathrm{p} . \mathrm{m}$. the temperature was $88^{\circ} \mathrm{F}$. inside and $9 \mathrm{I}^{\circ} \mathrm{F}$. outside the box. At no time were the plants covered while rain was falling. During dry weather both sets of plants were watered alike.

In the case of Flax, Wheat, White Mustard, and Soy Bean the seeds on the darkened plot were sown in two rows, the distance between the rows being nine inches. The seeds on the exposed plot were sown in exactly the same manner, and an interval of eighteen inches separated the darkened from the exposed plot. There were thus four parallel rows of the same length in which the soil was apparently quite uniform. The Sunflower seeds were sown in two parallel rows with an interval of twenty-four inches between the exposed and the darkened row.

\section{Flax in Open Ground, I92I.}

The seeds were sown on 23 May. On 6 June sixty-three plants were left on each plot, the number being gradually narrowed down to forty, at which figure they remained to the close of the experiment. The plot was darkened for seventy hours extending from 6 June to 25 June, and on sixteen days the weather was either sunny or partly sunny at the time. In the exposed plot seven plants came into flower on 3 July, and on 6 July thirty-nine were in flower. On the latter date the first plant came into flower on the darkened plot.

The heights and weights of the plants when they were pulled up on I2 July were as follows:

$\begin{array}{lcccc} & \begin{array}{c}\text { Average } \\ \text { height of } \\ \text { stem. }\end{array} & \begin{array}{c}\text { Tallest } \\ \text { plant. }\end{array} & \begin{array}{c}\text { Total } \\ \text { weight. }\end{array} & \text { No. in } \\ & \mathrm{mm} . & \mathrm{mm} . & \text { grm. } & \\ \text { Exposed plot } & 566 \cdot 3 & 780 & \text { I 70.100 } & 40 \\ \text { Darkened plot } & 553 \cdot 5 & 697 & \text { 106.310 } & 35\end{array}$

\section{Wheat in Open Ground, I92I.}

The seeds were sown on 23 May. On 2 June twenty-two plants were left in each plot, the number being afterwards reduced to nineteen. The plot was darkened for seventy hours from 2 June to 2 I June, the weather being sunny for the greater part of the time. In the exposed plot one plant came into ear on 7 July and on I 2 July, fourteen were in ear. In the darkened plot the first three plants came into ear on the latter date. The plants were pulled up on 16 July with the following results : 


$\begin{array}{lccccc} & \begin{array}{c}\text { Average } \\ \text { height of } \\ \text { stem. }\end{array} & \begin{array}{c}\text { Tallest } \\ \text { plant. }\end{array} & \begin{array}{c}\text { Total } \\ \text { weight. }\end{array} & \begin{array}{c}\text { No. of plants } \\ \text { in ear. }\end{array} & \begin{array}{c}\text { Total No. } \\ \text { of ears. }\end{array} \\ & \mathrm{mm} . & \mathrm{mm} . & \text { grm. } & & \\ \text { Exposed plot } & \mathbf{5 8 5 . 5} & 800 & 283.500 & 19 & 49 \\ \text { Darkened plot } & 44^{8} \cdot 7 & 662 & 19 \mathrm{I} \cdot 360 & \text { I5 } & \text { I8 }\end{array}$

White Mustard in Open Ground, I92I.

Seeds were sown on 23 May, and on 2 June forty-two plants were left in each plot, the number being afterwards reduced to twenty-seven. The period of darkening was exactly the same as for wheat. In the exposed plot six plants came into flower on 27 June, and on 30 June eighteen were in flower. On the latter date the first plant in the darkened plot came into flower. The plants were pulled up on 5 July with these results :

$\begin{array}{lcccc} & \begin{array}{c}\text { Average } \\ \text { height of } \\ \text { stem. }\end{array} & \begin{array}{c}\text { Tallest } \\ \text { plant. }\end{array} & \begin{array}{c}\text { Total } \\ \text { weight. }\end{array} & \begin{array}{c}\text { No. of } \\ \text { plants in } \\ \text { flower. }\end{array} \\ & \mathrm{mm} . & \mathrm{mm} . & \mathrm{grm} . & \\ \text { Exposed plot } & 6 \mathrm{I} 6.0 & 790.0 & 1006 \cdot 425 & 25 \\ \text { Darkened plot } & 460.7 & 647.0 & 453.590 & 17\end{array}$

\section{Soy Bean No. I in Open Ground, I92I.}

The seeds were sown on $23 \mathrm{May}$, and on 2 June eighteen plants were left in each plot, the number being reduced later to seventeen. The period of darkening was exactly the same as for wheat. In the exposed plot two came into flower on 4 July, and on 6 July three were in flower. The first flower in the darkened plot opened on the latter date. The plants were pulled up on I 2 July with the following results :

$\begin{array}{ccccc} & \begin{array}{c}\text { Average } \\ \text { height of } \\ \text { stem. }\end{array} & \begin{array}{c}\text { Tallest } \\ \text { plant. }\end{array} & \begin{array}{c}\text { Total } \\ \text { weight. }\end{array} & \begin{array}{c}\text { No. of } \\ \text { plants in } \\ \text { flower. }\end{array} \\ & \mathrm{mm} . & \mathrm{mm} . & \text { grm. } & \\ \text { Exposed plot } & 45^{2 \cdot 7} & \mathbf{5 2 8} & 5 \mathrm{5} 7 \cdot 380 & \mathrm{I} 7 \\ \text { Darkened plot } & 316 \cdot 3 & 399 & 226.800 & \mathrm{I} 7\end{array}$

Soy Bean No. 2 in Open Ground, I92I.

The seeds were sown on 23 May, and on 2 June sixteen plants were left in each plot, the number remaining the same to the end of the experiment. The period of darkening extended from 2 June to 25 June and comprised eighty-four hours. In both the exposed and darkened plots the first two flowers appeared on 2 July. The plants were pulled up on II July with these results :

$\begin{array}{lcccc} & \begin{array}{c}\text { Average } \\ \text { height of }\end{array} & \begin{array}{c}\text { Tallest } \\ \text { plant. }\end{array} & \begin{array}{c}\text { Total } \\ \text { seight. }\end{array} & \begin{array}{c}\text { No. of } \\ \text { plants in } \\ \text { flower. }\end{array} \\ & \mathrm{mm} . & \mathrm{mm} . & \mathrm{grm} . & \\ \text { Exposed plot } & 440 \cdot 4 & 555 & 467 \cdot 760 & 15 \\ \text { Darkened plot } & 358 \cdot \mathrm{I} & 446 & 262 \cdot 240 & \mathrm{I} 6\end{array}$




\section{Sunflower No. I in Open Ground, I92I.}

The seeds were sown on 23 May, and on 2 June twelve plants were left in each plot, which number remained to the end of the experiment. The time of darkening extended from 2 June to 2I June and comprised seventy hours. In the exposed plot five plants were in flower on 23 August and ten. on $3 \mathrm{I}$ August. The first flower in the covered plot opened on the latter date. On 6 September the stems were cut off at the ground level, the roots being left in the ground. The results were :

$\begin{array}{cccccc} & \begin{array}{c}\text { Average } \\ \text { height of }\end{array} & \begin{array}{c}\text { Tallest } \\ \text { plant. }\end{array} & \begin{array}{c}\text { Average } \\ \text { weight of } \\ \text { stem. }\end{array} & \begin{array}{c}\text { Heaviest } \\ \text { plant. }\end{array} & \begin{array}{c}\text { No. of. } \\ \text { plants in } \\ \text { flower. }\end{array} \\ & \mathrm{cm} . & \mathrm{cm} . & \text { grm. } & \text { grm. } & \\ \text { Exposed plot } & 257 \cdot 39 & 294 \cdot 64 & \mathrm{I} 808 \cdot 460 & 2863 \cdot 290 & \mathrm{I} 2 \\ \text { Darkened plot } & 197 \cdot 27 & 251 \cdot 46 & 444 \cdot 14 & 1417 \cdot 470 & \mathbf{5}\end{array}$

\section{Sunflower No. 2 in Open Ground, I92I.}

The seeds were sown on 23 May, and on 2 June fourteen plants were left in each plot, the number being afterwards reduced to twelve. The period of darkening was exactly the same as in the case of Wheat. In the exposed plot the first plant came into flower on 25 August, and on 2 September four were in flower. The first flower in the darkened plot opened on the latter date. The stems were cut at the ground level on 7 September. The results were:

$\begin{array}{lccccc} & \begin{array}{c}\text { Average } \\ \text { height of }\end{array} & \begin{array}{c}\text { Tallest } \\ \text { plant. }\end{array} & \begin{array}{c}\text { Average } \\ \text { weight of } \\ \text { stem. }\end{array} & \begin{array}{c}\text { Heaviest } \\ \text { plant. }\end{array} & \begin{array}{c}\text { No. of } \\ \text { plants in } \\ \text { flower. }\end{array} \\ & \mathrm{cm} . & \mathrm{cm} . & \text { grm. } & \text { grm. } & \\ \text { Exposed plot } & 273.05 & 294.64 & \mathrm{I} 434.000 & 5^{\mathrm{I}} 45.4 \mathrm{IO} & \mathrm{I} 2 \\ \text { Darkened plot } & 237.49 & 274.3^{2} & 682.750 & \mathrm{I}_{2} 33.200 & 5\end{array}$

Experiments with Indian Corn and Wax Bean in Open Ground, I92I.

In this series there were twelve rows, six being Indian Corn and six Wax Bean. Each pair of rows was of approximately equal length, and one row of each pair was darkened, while the other was exposed to daylight. The seeds in all the rows were sown on 17 June and the period of darkening extended from 27 June to 13 July, the sunny days during the time of darkening being slightly in excess of the cloudy days. One row of Indian Corn was darkened on the average for two hours daily, another for three and a half hours daily, and the third for five hours daily, the procedure in the case of the rows of Wax Bean being similar. The average length of daylight between 27 June and I 3 July was about fifteen and a half hours, reckoned from sunrise to sunset. 


\section{Indian Corn No. $I$.}

There were six plants in each row. One row was darkened for thirtyfour hours, or an average of two hours daily, the actual time of darkening varying from thirty-five minutes to six hours on any one day.

On 29 July the exposed plot had three plants with staminate inflorescences protruding, while on the darkened plot only one was protruding.

\section{Indian Corn No. 2.}

There were nine plants in each row. The period of darkening amounted to fifty-nine and a half hours, or an average of three and a half hours daily, the actual time of darkening varying from one hour to seven hours on any one day.

On the exposed plot five plants had staminate inflorescences protruding on 29 .July, while on the darkened plot there were four with staminate inflorescences.

\section{Indian Corn No. 3 .}

There were thirteen plants in each row, which were afterwards reduced to twelve. The period of darkening amounted to eighty-five hours, or an average of five hours daily, the actual time of darkening varying from one and a half hours to eight hours on any one day.

On the exposed plot on 29 July eleven plants had staminate inflorescences protruding, while only one was visible on the darkened plot.

On 23 August twelve plants on the exposed plot bore pistillate flowers, while on the darkened plot there was only one with pistillate flowers.

The plants were pulled up on 8 September with the following results:

\begin{tabular}{|c|c|c|c|}
\hline & $\begin{array}{c}\text { Average height } \\
\text { of stem. } \\
\mathrm{cm} .\end{array}$ & $\begin{array}{l}\text { Tallest } \\
\text { plant. } \\
\mathrm{cm} .\end{array}$ & $\begin{array}{l}\text { Total } \\
\text { weight. } \\
\text { grm. }\end{array}$ \\
\hline Exposed plot & I $24 \cdot 35$ & ${ }^{1} 53.67$ & 2353.000 \\
\hline kened plot & $8 \mathrm{I} \cdot 23$ & $121 \cdot 9^{2}$ & $1247 \cdot 380$ \\
\hline
\end{tabular}

Wax Bean No. I.

There were seven plants in each row. The period of darkening was the same exactly as in Indian Corn No. I, and averaged two hours daily.

On 20 July three plants were in flower on the exposed plot, while there was only one on the darkened plot.

The plants were pulled up on 23 July with these results :

$\begin{array}{cccc} & \text { Average height } & \text { Tallest } & \text { Total } \\ & \text { of stem. } & \text { plant. } & \text { weight. } \\ & \mathrm{mm} . & \mathrm{mm} . & \mathrm{grm} . \\ \text { Exposed plot } & 393.7 & 5 \circ 5 & \mathrm{I} 4 \mathrm{I} \cdot 750 \\ \text { Darkened plot } & 382.6 & 45^{2} & \mathrm{I} 34.660\end{array}$




\section{Wax Evan No. 2.}

There were ten plants in each row. The period of darkening was the same as in Indian Corn No. 2, and averaged three and a half hours daily.

On 20 July on the exposed plot five plants were in flower, while on the darkened plot four were in flower on the same date.

The plants were pulled up on 23 July with these results :

$\begin{array}{cccc} & \begin{array}{c}\text { Average height } \\ \text { of stem. }\end{array} & \begin{array}{c}\text { Tallest } \\ \text { plant. }\end{array} & \text { Total } \\ & \mathrm{mm} . & \mathrm{mm} . & \text { wrm. } \\ \text { Exposed plot } & 366.9 & 434 & 219 \cdot 7 \mathrm{IO} \\ \text { Darkened plot } & 335.6 & 422 & 170 \cdot 100\end{array}$

\section{Wax Bean No. 3 .}

There were sixteen plants in each row, which were afterwards reduced to fourteen. The period of darkening was the same as in the case of Indian Corn No. 3, namely, five hours daily on the average.

On the exposed plot on 20 July eight plants were in flower, while on the darkened plot there were none. The first flower on the darkened plot opened on 22 July, on which date eleven were in flower on the exposed plot.

The plants were pulled up on $25 \mathrm{July}$ with the following results :

$\begin{array}{lccc} & \begin{array}{c}\text { Average height } \\ \text { of stem. }\end{array} & \begin{array}{c}\text { Tallest } \\ \text { plant. }\end{array} & \begin{array}{c}\text { Total } \\ \text { weight. }\end{array} \\ & \mathrm{mm} . & \mathrm{mm} . & \text { grm. } \\ \text { Exposed plot } & 53 \mathrm{I} \cdot 0 & 8 \mathrm{I} 5 & 4 \mathrm{II} .080 \\ \text { Darkened plot } & 3 \mathrm{I} 7.5 & 425 & 219.7 \mathrm{IO}\end{array}$

\section{Experiments with Tomato in Greenhouse, I92I.}

There were twelve pots with one plant in each. Four of these were left uncovered, and the remainder were darkened in sets of four each, the period of darkening being the same in each four. Wooden boxes were used as covers. The seeds were planted on 23 May. The period of darkening extended from 6 June to 30 June and comprised altogether ninety-two and a half hours, or an average of three hours forty-two minutes per day. This made the daily periods of light and darkness approximately equal. The actual time of covering on any one day varied from two to six hours. The different pots received approximately the same amount of water.

In the exposed pots the first plant came into flower on 4 July, and on 7 July all four were in flower.

In the first series of darkened pots the first two plants came into flower together on I I July, while in the second series of darkened pots the first plant came into flower on 9 July. 
The plants were cut at the ground level on 18 July with the following results :

\begin{tabular}{|c|c|c|c|}
\hline & $\begin{array}{c}\text { Average height } \\
\text { of stem. } \\
\mathrm{mm} .\end{array}$ & $\begin{array}{c}\text { Tallest } \\
\text { plant. } \\
\mathrm{mm} .\end{array}$ & $\begin{array}{l}\text { Total } \\
\text { weight. } \\
\text { grm. }\end{array}$ \\
\hline $\begin{array}{l}\text { Exposed pots } \\
\text { Darkened pots, Ser. I }\end{array}$ & $\begin{array}{l}295 \cdot 5 \\
255 \cdot 0\end{array}$ & $\begin{array}{l}310 \\
283\end{array}$ & $\begin{array}{l}77 \cdot 970 \\
63 \cdot 790\end{array}$ \\
\hline$, \quad, \quad, \quad 2$ & $294 \cdot 5$ & 330 & $77 \cdot 970$ \\
\hline
\end{tabular}

\section{Experiments with Dandelion in Greenhouse, I92I-2.}

Seeds were obtained from plants which had flowered in I92I and on which the seeds were ripe in the month of May. Two pots were sown on 28 May I92I, and subsequently five plants were left in each pot. One of the pots was darkened periodically, a wooden box being used for the purpose, while the other pot was exposed to daylight. The period of darkening extended from 16 June to 30 July and included altogether I $57 \frac{1}{2}$ hours, about two-thirds of the time being sunny.

On 3I August one flower head in the darkened pot opened, but there was none on that exposed to light. The five plants in the latter case were larger than those in the darkened pot. No further flowers were produced during the year I92I. On 29 March 1922 the first head in the pot exposed to light opened, while the first head in the darkened pot did not open until 3 April.

The total number of flower heads produced by the five plants in the pot exposed to light was twenty-two, while in the darkened pot the total number of heads was nine. In the darkened pot both plants and heads were smaller than in the case of the pot exposed to light.

\section{Experiments with Liver-leaf (Hepatica acutiloba, DC.) in Greenhouse.}

In order to test the effect of a shortened period of light on plants which grow naturally in the shade of a forest, two species were experimented with, namely Liver-leaf (Hepatica acutiloba, DC.) and Coolwort (Tiarella cordifolia, L.). It might naturally be expected that to much light in the case of such plants would have an injurious effect.

Six plants of Liver-leaf were dug up from the floor of a wood and placed in pots on 20 June 1921. The plants were approximately of the same size. After they had become properly established in the pots, three were darkened from 4 July to 30 July. The total time of darkening amounted to ninety-four and a half hours. The weather during about twothirds of the time of covering was sunny.

The dates of opening of the first flower in the three pots exposed to light were respectively 20 February 1922, 28 February 1922, and 8 March I922.

The corresponding dates in the three darkened pots were I March I922, 6 March I922, and Io March I922. 
The total number of flowers produced in each of the three pots exposed to light was sixteen, twenty-two, and twenty, while in the darkened pots the numbers were twenty-four, fifteen, and thirteen.

\section{Experiments with Coolwort (Tiarella cordifolia, L.) in Greenhouse.}

The time of planting and the dates and duration of covering were exactly the same as for Liver-leaf.

The first flower in the three pots exposed to light opened on 25 March 1922, 29 March 1922, and 2 April 1922, respectively. In the darkened pots the corresponding dates were 27 March 1922, 29 March 1922, and I April I922.

The total number of flowering scapes in the pots exposed to light was fourteen, seventeen, and twenty-one respectively, while in the darkened pots the numbers were eighteen, seventeen, and twenty.

\section{Discussion of Results.}

From the above experiments the following conclusions may be drawn:

I. The plants exposed longest to the action of light $(a)$ attained the greatest weight, $(b)$ attained the greatest average height, $(c)$ commenced to flower earlier than those which were darkened for a number of hours each day.

2. The above results were not so marked in the case of Soy Bean and Tomato.

3. In latitude $45^{\frac{1}{2}}$, where the experiments were carried out, the other plants were able to make use of the prolonged daily period of light during the summer months with beneficial results.

Some further comment on these results seems desirable in view of the conflicting conclusions arrived at by the other investigators whose views were briefly summarized above. Apparently some restatement of the action of light on plants is necessary.

I $a$. As light of a certain intensity is necessary for photosynthesis, it necessarily follows that, if other conditions remain the same, the plants exposed longest to light will attain the greatest weight, and this was confirmed by the experiments.

I $b$. As growth in length normally takes place as the result of celldivision and cell-elongation at or near the tip of the stem, and as organic material is required for such cell-division, it necessarily follows that plants provided with a larger supply of such material as the result of prolonged photosynthesis are in a better position for making increased growth than those not so well supplied. ${ }^{-}$Hence plants with a longer period of illumination should attain a greater height than those illuminated for a shorter time (other conditions remaining the same), which again is borne out by the experiments.

A better understanding of the situation will be arrived at if attention 
is concentrated on what takes place in a single cell of the spongy parenchyma of the leaf during daylight.

At the points where such a cell is in contact with neighbouring cells, water and certain inorganic substances in solution, which have been absorbed by the roots and have travelled up the vessels of the stem, are passing into the cell in question.

Where the cell-wall abuts on an air-space, water is passing through the cell-wall and is being evaporated, eventually diffusing through the open stoma into the atmosphere.

Certain organic substances in the cell are being broken down, with the formation of carbon dioxide as a result.

Carbon dioxide is being used by the chlorophyll corpuscles for the manufacture of starch grains or other carbohydrate.

Enzymes are at work within the cell, transforming starch into sugar and effecting various other changes.

An exosmosis of elaborated products is taking place through the points of contact of the cell with other cells, which elaborated products eventually find their way into the sieve-tubes and are conducted to the growing regions or places of storage within the plant.

At night or during darkness the stomata close, there is no diffusion of water vapour or other gases from the interior of the plant to the outer atmosphere, photosynthesis ceases, and the flow of water into the cell from the vessels stops or is reduced to a minimum. The conditions are therefore most favourable for the action of enzymes on the accumulated products of photosynthesis and the translocation of materials to the growing tissues of the plant. If the night temperature is sufficiently high, an extension in length of the stem would be the natural result.

It is not claimed here that every relation of a plant to light is capable of explanation in this way, but only its growth during darkness.

I $c$. A plant normally flowers after it has attained a certain height and has stored up a quantity of reserve materials within its tissues. This is illustrated by biennial plants, bulbs, \&c. A plant growing in dull light may have such a struggle for existence that it has no reserve material worth mentioning. As a result it will either not flower or will produce flowers very sparingly. Some trees in certain seasons produce such an abundance of flowers and fruits that it requires an interval of one or sometimes two years before the tree can accumulate sufficient reserve material for the formation of flowers again.

As has been proved by the experiments, those plants subjected to a longer period of illumination grew faster and attained a greater weight as the result of prolonged photosynthesis. They would therefore naturally be in a position to bear flowers before those plants subjected to a shorter period of daylight. 
2 and 3 . The behaviour of Soy Bean and Tomato as compared with the other plants tested would tend to indicate that there is a certain optimum relation between the daily amounts of light and darkness within which a plant will attain its best development. But probably further experiments with these two species are necessary before any broad conclusions can be drawn.

In the case of the other species experimented with, which grow naturally farther north, they were able to utilize the full period of daylight during the summer months with good effect. Kjellman's experiments showed that continuous illumination for twenty-four hours in the arctic regions produced better results than twelve hours of light and twelve of darkness. Until, however, some experimenter tests the result of exposure to eighteen hours of light and six of darkness or twenty-one of light and three of darkness daily, it would probably be rash to assume that in the case of plants growing in temperate climates there is no upper limit to the daily optimum amount of light.

\section{SUMMARY.}

The effect on certain plants was noted of excluding light for a number of hours during the months of June and July, when the normal period of daylight in latitude $45^{\frac{1}{2}}$ is greatly in excess of the period of darkness. Some of the plants were covered for a period of three and a half hours, thus equalizing the duration of light and darkness; in other cases the plants were darkened for one, two, or five hours, on the average, for each day.

Some of the experimental plants were grown in pots in a greenhouse, others were planted inside a frame, while still others were planted in open ground. To exclude the light, large inverted flower-pots were used, also sheets of brown paper fastened to frames, and in other cases large wooden boxes were employed for the purpose. Care was taken to keep all the other conditions as uniform as possible.

The plants experimented with were Wheat, Indian Corn, Liver-leaf, White Mustard, Soy Bean, Wax Bean, Flax, Coolwort, Tomato, Sunflower, and Dandelion.

In almost all cases the plants exposed longest to the action of light gave the following results:

(a) Greatest average weight, (b) greatest average height, (c) earliest flowers.

The conclusion is drawn that growth or extension in length can take place both in light and in darkness, and that in both cases the amount of growth within a definite period of time is largely determined by the supply of available reserve material and the readiness with which this can be drawn upon by the growing parts. 


\section{LITERATURE.}

1. Schübeler, F. C.: Studier over Klimatets Indflydelse paa Plantelivet. Naturen, Aarg. 3, No. 6, pp. 8I-89, and No. 8, pp. I1 $3-23$. 1879 .

2. Engelmann, T. W.: Untersuchungen über die quantitativen Beziehungen zwischen Absorption des Lichtes und Assimilation in Pflanzenzellen. Bot. Ztg., xlii. 8I-I06, I884.

3. Kjellman, F. K.: Aus dem Leben der Polarpflanzen. In Nordenskjöld, Studien und Forschungen veranlasst durch meine Reise im hohen Norden. Leipzig, 1885 .

4. Istranffi, G. : Influence of Light upon the Development of Flowers, I890.

5. Curtel, G. : Recherches physiologiques sur la transpiration et l'assimilation pendant les nuits norvégiennes. Revue générale de botanique, tome ii, $\mathrm{I} 890$.

6. Bailey, L. H.: Some Preliminary Studies of the Influence of the Electric Arc Lamp upon Greenhouse Plants. Cornell Agr. Exp. Sta. Bull., xxx. 83-I 22, I89I ; also xlii. I3I-46, I 892 ; and 1 v. $145-57, \mathrm{I} 893$.

7. Vöchting, H.: Ueber den Einfluss des Lichtes auf die Gestaltung und Anlage der Blüthen. Jahrb. f. wiss. Bot., xxv. I 49, I893.

8. Rane, F. W.: Electro-horticulture with the Incandescent Lamp. W. Va. Agr. Exp. Sta. Bull., xxxvii, I894.

9. Bonnier, G. : Influence de la lumière électrique continue sur la forme et la structure des plantes. Revue générale de botanique, vii. 24I, 289, 332, 407, I895.

10. Curtel, M. Y. : Recherches physiologiques sur la fleur. Ann. Sci. Nat., VIII, vi. 220, r897.

11. Corbett, L. C. : A Study of the Effect of Incandescent Gas-light on Plant Growth. W. Va. Agr. Exp. Sta. Bull., 1xii. 77-110, I899.

12. Pfeffer, W.: Physiology of Plants. English translation by A. J: Ewart, Oxford, 1900-1906.

13. Macdougal, D. T.: The Influence of Light and Darkness upon Growth and Development. Mem. New York Bot Gard., ii. I-319, I903).

14. Schimper, A. F. W. : Plant Geography upon a Physiological Basis. English translation, Oxford, 1903 .

15. Osterhout, W. J. V.: Experiments with Plants. 3rd ed., New York, I 906.

16. Wiesner, J.: Der Lichtgenuss der Pflanzen. Leipzig, i9o7.

I 7. Nathansohn, A., and Pringsheim, E. : Über Summation intermittierender Lichtreize. Jahrb. f. wiss. Bot., xlv. I37-190, I908.

18. Warming, E., and Vahl, M.: Oecology of Plants. English translation by P. Groom and I. B. Balfour, Oxford, I909.

19. Duggar, B. M. : Plant Physiology with Special, Reference to Plant Production. New York, I9II.

20. Hayden, J. L. R., and Steinmetz, C. P. : Effect of Artificial Light on the Growth and Ripening of Plants. Gen. Elec. Rev., xxi. 232, I918.

21. Boysen-Jensen, P. : Studies on the Production of Matter in Light and Shadow Plants. Bot. Tidsskr., xxxvi. 219-59, I918.

22. Palladin, V. I.: Plant Physiology. English translation by B. E. Livingston, Philadelphia, I9I8.

23. De Besteiro, D. C., and Durand, M. : Influence de la lumière sur l'absorption des matières organiques du sol par les plantes. Compt. Rend. Acad. Sci. Paris, clxviii. 467-70, I9r9.

24 . par les racines des plantes supérieures. Rev. Gén. Bot., xxxi. 94-Io8, I9I9.

25. Wiessmann, H.: Einfluss des Lichtes auf Wachstum und Nahrstoffaufnahme beim Hafer. Landw. Jahrb., xxxv. I83-90, I919.

26. Illick, J. S. : When Trees grow: a Novel Study. Can. For. Journ., xv. 35I-4, I9I9.

27. Garner, W. W., and Allard, H. A. : Effect of the Relative Length of Day and Night and other Factors of the Environment on Growth and Reproduction in Plants. Journ. Agr. Research, xviii. 55.3-606, Mar. 1920.

28. Adams, J. : Relation of Flax to Varying Amounts of Light. Bot. Gaz., lxx. I53-6, Aug. I920. 29. Schanz, F.: The Effects of Light on Plants. Sci. Amer. Monthly, i. 12-I6, Igzo. 
94 Adams. - The Effect of altering the Light on Certain Plants.

30. Massart, J. : L'action de la lumière continue sur la structure des feuilles. Acad. Roy. Belgique, Bull., Cl. Sci., pp. 37-43, 1920.

31. Stiles, W. : Influence of Environmental Factors on Growth and Development of Plants. Science Progress, xiv. 392-6, I920.

32. Garner, W. W., and Allard, H. A. : Flowering and Fruiting of Plants as controlled by the Length of Day. U.S. Dep. Agr. Yearb. (1920), pp. 377-400, I92I.

33. Oakley, R. A. and Westover, H. L.: Effect of the Length of Day on Seedlings of Alfalfa Varieties and the Possibility of utilizing this as a Practical Means of Identification. Journ. Agr. Research, xxi. 599-607, 192 I.

34. Brown, E. B., and Garrison, H. S. : Effect of Date of Seeding on Germination, Growth, and Development of Corn. U.S. Dep. Agr., Bull. IoI 4, pp. I-I I, Washington, I922. 


\section{$2 \mathrm{BHL}$ Biodiversity Heritage Library}

Adams, J. 1923. "The effect on certain plants of altering the daily period of light." Annals of botany 37, 75-94.

https://doi.org/10.1093/oxfordjournals.aob.a089838.

View This Item Online: https://www.biodiversitylibrary.org/item/270686

DOI: https://doi.org/10.1093/oxfordjournals.aob.a089838

Permalink: https://www.biodiversitylibrary.org/partpdf/319069

\section{Holding Institution}

New York Botanical Garden, LuEsther T. Mertz Library

\section{Sponsored by}

BHL-SIL-FEDLINK

\section{Copyright \& Reuse}

Copyright Status: Public domain. The BHL considers that this work is no longer under copyright protection.

This document was created from content at the Biodiversity Heritage Library, the world's largest open access digital library for biodiversity literature and archives. Visit BHL at https://www.biodiversitylibrary.org. 